\title{
Developing Media of Picture Book In Early Reading Learning At the Age 5 To 6 Years
}

\author{
Desy Ayu Permatasari, Fetty Shofia Adiba, Suparno \\ Post Graduate, Yogyakarta State University, Yoogyakarta, Indonesia \\ e-mail: Dezi.ayu@gmail.com
}

\begin{abstract}
Developing Media of Picture Book in Early Reading Learning at the Age 5 to 6 Years. Desy Ayu P, 1,2Graduate School, Yogyakarta State University Abstract : This research aimed to :1) develop a media picture book based on field studies, needs analysis study in kindergarten literature found in TK Aisiyah at Cepu Sub-district in early reading learning of Group B, 2) and to find out the Effectiveness of picture Book media in early reading learning in Group B. The type this reseach was a Reseach \& Development which adapted from Borg \& Gall model with the following phases: 1) early study-field, 2) planing, 3) development of draft/prototype 4) validating the product, 5) test of feasibility, 6) and test of effectiveness. The subject of small field testing consisted of 4 teachers and 9 teachers from TK Muhammadiyah, the large testing subjects were 6 students of TK Mutiara Insani,TK tunas Harapan, TK Assalam. The subject of effectiveness test were 14 student of TK Migas as the experiment class, and 15 student of TK Bhayangkari as the control class. The data were collected using the guidelines of the interview, quesionnaire for product by teachers, the observation sheet and quesionnaire of student's respons. The data were analyzed using the independent samples T-test with significance level 0.05 . The result of feasibility test on a small field testing in terms of design gained average 37,5 and the content had 42,25 . It was "very good" criteria. On the large field testing, the result from design had an avarege 42.33 and the content had 47.5. it had the "very good" criteria. The effectiveness of test result found there was a significant difference in early reading leaning between thr control class and the experimental class with $\mathrm{p}=0.003$ where $\mathrm{p}<0.05$.
\end{abstract}

Keywords: Development,Picture Book Media,Early Reading Learning,Childhood

\section{INTRODUCTION}

Early Education is an education that serves 0 to 6 years old children in order to develop the children's skills optimally. The skills include language aspect, cognitive, physical motor, social emotion, and religion and moral values of children. Piaget [1] believes that children develop knowledge through interaction with environment. Children set their experience into complex mental structures. Based on the results of observation conducted by teachers, children that are taught using conventional method have difficulties in recalling the name of letter in words. According to Denton and West [2], reading and early numeracy during kindergarten have positive contribution toward reading and mathematics abilities and skills of children when in kindergarten and grade I elementary school. For that reason, the success of early reading process is crucial to be made as the foundation for reading and mathematics abilities and skills of children when they are in kindergarten and grade I elementary school. Therefore, the success of early reading is crucial to be made as the foundation for further reading ability and other academic abilities.

Durkin concludes if there are no negative effects on children that have acquired early reading stimulation. Steinberg [3] in the same book also finds that children that receive early reading subject are generally more advanced in school.

Early reading learning activity in the implementation of learning in TK Islam in Cepu 
sub-district has yet to accommodate the needs and characteristics of the children's development. While implementing early reading learning, the teachers do not start the learning by conducting a screening first towards the readiness of the children in reading. It is the reason why teachers do not have enough prior knowledge in implementing the correct early reading learning for children and their level of development.

The use of picture book media for learning in kindergarten is still limited to story telling learning, and is not included in early reading learning through letters, words, and sentences followed by pictures so that children do not only read sentences in their reading activity but the children also realize that the sentences have meanings through the available picture illustrations. Experience in early reading can grow consciousness of more meaningful reading for children.

The intention of this research is to develop learning media for the introduction of early reading in PAUD. The development of this learning media is expected to help and make it easier for teachers in implementing early reading learning practice for young children.

Theories which become the foundation for the development of this learning media are the perspective put forwarded by nativism who argues that the development of children's language is natural and behavioristic perspective who argues that language mastery is an ability which comes from cognitive maturity (Chaer, 2009:221). The three perspectives of language acquisition are further explained as follow: behaviorism theory views language development as a progress of capturing verbal through the principles of stimulation and responds in imitating process. Behaviorism believes that language is acquired through speech exposures from adults (Musfiroh, 2017:21). Nativism theory argues that language cannot be learned through imitation process instead of a mental, which means that language acquisition process is not influenced by environment. According to Chomsky, human beings are born with a set of language instruments called LAD (Language Acquisition Device). The Inputs received by someone are not directly received by LAD, but the inputs have to go through filtering process by affective filters (Musfiroh, 2017:22). According to Jordan, Charlie \& Stack, cognitivism theory are 1) sensations, in which are the stimulation process received by sensory system and forwarded to information processing system, 2) perception is a translation process of information received by senses, 3) attention is an effort to focus concentration on matters considered important and to ignore matters that are not important, 4) encoding is a translation process of information in which the result is mental representation in form of scheme, 5) memory is an ability of someone to memorize and recall information acquired from previous cognitive stages.

Constructivism-Interactionism views that human beings construct their understanding and knowledge through understandings and reflections from many previously acquired experiences (Mushfiroh, 2017:27). It can be interpreted that knowledge acquired by someone does not merely a new thing, but there are processes of constructing new experience with previous experience that has been acquired from social culture contexts. Woolfolk (2009:82-84) states that cultural tools can be passed from one individual to other individuals through 3 processes. The processes are 1) initiative learning in which the learner imitates, 2) instructed learning in which the learners internalize the learning delivered by teachers and use it to regulate themselves, and 3) collaborative learning in which the learners are learning from one and another. It proves that in learning process, individuals are influenced by their environment. Adults have roles in helping children to learn through scaffoldings that can be in form of clue, reminder, push, problem analysis, giving example or helping the children to learn independently.

According to the opinion of Vigotsky, Brunner and Panteleo in Sarjiono (2009) about language and thinking, it can be defined that language development cannot be separated from the development of children's cognitive. When children develop their language skills, cognitive of the children also develops in processing information needed in the process of the children's development. Language allows children to express their experience though symbols that can be used to communicate and think.

Language development of young children especially those who are 5 to 6 years old experience rapid development along their cognitive and social life development. Early reading is one of the language development aspects of children. Language development of children is related to their early literation skills which marks the readiness of children in early reading. Language development of children depends on the mastery of language when the children have to own phonetic, semantic, 
morphemic and pragmatic knowledge. This language mastery skill is the one that influences children's ability in early reading.

There are several methods in early reading learning, they are phonic and complete language method. Method used in the introduction of early reading learning is adjusted with the characteristics of children acquired from previous study through interview of teachers, parents, and children, observation and study of documentation or children's portfolio.

Development of science and technology further encourages renewal efforts in making use of technology in learning process. It requires the teacher to be capable of using those tools according to the current development. The teachers at least have to know how to use cheap and efficient tools. Even though it is simple, but it is a must in order to achieve learning purpose expected. For that reason, teachers have to own enough knowledge about learning media.

Looking at the existing cases, learning will be more effective if it is helped with interesting learning media in form of a game. The theories and research background are the basic cause for picture book media to be developed in order to increase the ability of early reading for young children. In dealing with the difficulties, learning media implemented in the learning process has a pretty big role in the success of a learning process, just like learning media is used in order for learning process to run actively and interestingly so that it can increase learning achievement in early reading learning for young children.

\section{METHOD}

Research method used in developing this picture book media is research and developed model put forwarded by Borg and Gall because this research model is in suitable to be implemented in this picture book media development. Development model of Borg and Gall has 6 steps in the process or steps to develop a product which can be seen in this scheme.

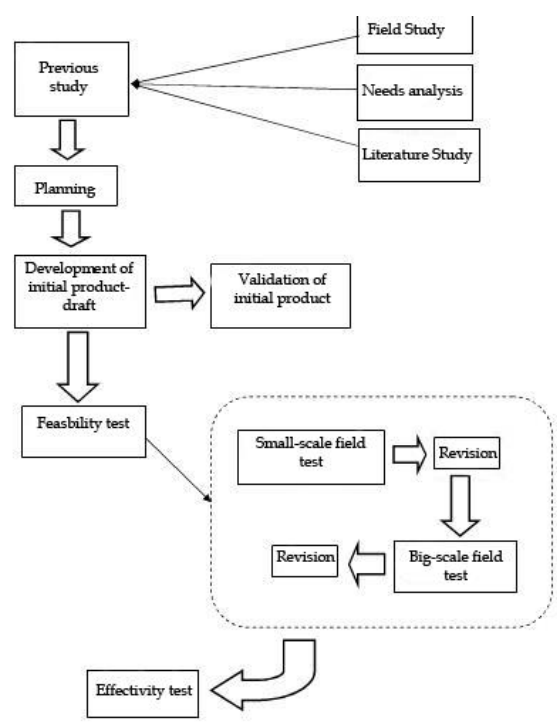

Figure 1 Picture book media development model adopted from Borg\& Gall model.

The product test design uses expert validation, and the feasibility test is conducted in small and bigscale field tests. The small-scale test is conducted to 12 kindergarten students that are chosen randomly as research subjects. The number of subject in this field test is selected according to the opinion of Borg and Gall (1987:775) who say that the subjects needed for preliminary field test can be from 1-3 schools that consist of 6-12 subjects. The implementation of this limited field test involves 12 students from group B and 4 students of TK Muhammadiyah Cepu. Bigscale field test is conducted by involving more children, which is by involving 5 schools and 7 teachers. The number of subject in this big-scale field test is selected according to the opinion of Borg and Gall (1983:775) who say that the subjects needed for field test can be from 5-15 schools that consist of 30-100 students. Within this step, information about responds and feasibility of the Picture Book product are collected from the teachers and students. After conducting the big-scale field test, the revision is also consulted with the teachers based on previous discussion. The effectivity test is conducted towards the research sample, which are TK Mutiara Insani and TK Aisiyah in Cepu. The effectivity test of the product uses observation with control and experiment classes.

Data collection techniques used in this research are interview, questionnaire and observation. The interview used is structured interview in order to know how the early reading learning is 
implemented, what media are used, availability of early reading media, and others. The questionnaire is used to collect the scores given by teachers or practitioners for the product in order to acquire criteria for a media that is considered feasible to be used. The observation is conducted in order to know the implementation of picture book media which is consisted in learning media during learning process, and after the learning has been implemented, conclusion on the use of picture book media is created

\section{RESULT AND DISCUSSION}

The product development was started by conducting field study for needs analysis and literature study. During the field study, it is found that in the early reading learning, the teachers do not conduct any screening first towards the readiness of children in reading. It causes the teachers to have no basic knowledge in implementing the correct early reading learning for the children and in accordance to their development. The children are not directly involved in creating the letters into words and meaningful sentences. It is of course not in accordance with the learning principles of young children that has to be meaningful, concrete, contextual and learning by doing. The use of learning media in introducing early learning is still less in accordance with the characteristics of children, so the children are not motivated, feeling bored and even feeling burdened during the process of early reading learning. The use of picture book media for learning in kindergarten is still limited to learning to tell stories, and is not included in early reading through the introduction of letters, words, and sentences followed with pictures. It is done so that in reading learning, the children don't just read sentences but also realize that the sentences have meanings through the picture illustration so it will grow their consciousness about more meaningful reading.

The product development procedure created is Picture book media which include a story about everyday activities. The kind of picture book developed is a story picture book which consists of pictures illustration completed with story text. The story text in picture book uses simple sentences with words that are familiar for the children. This picture book is also equipped with soft motoric activities made out of flannel and hard fabrics combination in order to support the introduction of letters and words. This picture book is created in several steps. The first step is the process of drawing the illustration by using pencil and crayon as coloring media. After the pictures have been through the finishing step, the scanning process can be done in order to get pictures in form of soft file. The illustration pictures are then edited to add the text by using Corel Draw X5 software, and then printed using $150 \mathrm{gr}$ art paper. Picture book media product includes the guidelines of how to use it and its acknowledgement. The content consists of a series of routine activities began when children wake up and go to school by emerging independent values of the children. The words used are simple and familiar for the children. Besides the story illustration, there are activity tasks which are related and support the story content that can be done by children. Within the wake up page, soft motoric activity that can be done by the children is to tell the clock when the children wake up and then the children embed the letters to form the word "jam (clock)". In a picture that shows the activity of taking a bath and brushing teeth, soft motoric activity that can be done by children is to pair buttons and construct the word "baju (shirt)" and close zippers and construct the word "celana (pants)". Picture that shows the activity of eating together is supported with an activity matching the food picture with the word which symbolizes it. Picture that shows the activity of saying farewell to parents before going to school is supported with activities of tying shoelace and introducing the word "sepatu (shoes)". The story is ended with picture of a child who goes to school on his own without his parents on the closing chapter.

Table 1. scores recapitulation of the media by expert

\begin{tabular}{lllll}
\hline Aspects & $\begin{array}{l}\text { Number } \\
\text { of items }\end{array}$ & $\begin{array}{l}\text { Number } \\
\text { of } \\
\text { indicator }\end{array}$ & $\begin{array}{l}\text { total number } \\
\text { of maximum } \\
\text { score }\end{array}$ & criteria \\
\hline Design & 11 & 32 & 44 & Good \\
content & 12 & 36 & 48 & Very good \\
overall & 23 & 68 & 92 & Very good \\
\hline
\end{tabular}

The minimum score set for the product in this research is "good" category. So, if the experts and teachers give at least "good" scores for the product, then the product developed is considered feasible to be used. Based on the scores of product given by experts, the design component is in "good" criteria, content component is in "very good" criteria and the overall scoring

is 
Feasibility test of the product in small scale is conducted for 3 days in order to collect recommendations from teachers and responds from students towards the picture book media. The researcher asks for the help of school teachers namely $\mathrm{B} 1$ and $\mathrm{B} 2$ to conduct the early reading learning by using the picture book media. The scores given by teachers for the picture book media are collected and the average scores of each component are then calculated. The scores given by teachers for picture book media acquired can be seen in the following table:

Table 2, Recapitulation of scores given by teacher

\begin{tabular}{|c|c|c|c|}
\hline \multirow[t]{2}{*}{ component } & \multicolumn{2}{|c|}{ Scores } & \multirow[t]{2}{*}{ criteria } \\
\hline & $\begin{array}{l}\text { total } \\
\text { Score }\end{array}$ & $\begin{array}{c}\text { Average } \\
\text { score }\end{array}$ & \\
\hline design & 150 & 37.5 & Very good \\
\hline Content & 169 & 42.25 & Very good \\
\hline $\begin{array}{c}\text { Overall } \\
\text { component }\end{array}$ & 319 & 80.8 & Very good \\
\hline
\end{tabular}

Based on the overall scores given by the teachers, the criteria acquired is in "very good" category. The scores for each component from design and content component are also "very good". But there are several recommendations given by the teachers that can be used as material to revise the picture book media. The teachers say that the color used in the picture embedded does not hold very well and will be disintegrated if it is used for a long time.

The big-scale field test is conducted 55 children at once in order to collect the responds of children toward the picture book media. The scores are collected and the average score of each component and also the overall score are calculated.

Scores of picture book media given by teachers can be seen in the following table:

Table 3. recapitulation of picture book media scores given by teacher in big scale field test

\begin{tabular}{|c|c|c|c|}
\hline \multirow[t]{2}{*}{ Component } & \multicolumn{2}{|c|}{ Scores } & \multirow[t]{2}{*}{ criteria } \\
\hline & $\begin{array}{l}\text { Total } \\
\text { score }\end{array}$ & $\begin{array}{l}\text { Average } \\
\text { score }\end{array}$ & \\
\hline design & 298 & 42.57 & Very good \\
\hline Content & 333 & 47.57 & Very good \\
\hline $\begin{array}{l}\text { Overall } \\
\text { component }\end{array}$ & 631 & 90.14 & Very good \\
\hline
\end{tabular}

Based on the overall scores given by the teachers, the criteria acquired for the media is in "very good" category, so as the scores of each component from the design and content components are also "very good". There are several recommendations from the teachers which become the material to revise the picture book media, which are to strengthen the book cover, to add more accessories in the book so that the children are more interested to use this picture book media. The product is revised according to the recommendations given by the practitioners. The book cover is strengthened by sewing the part using mattress thread with cross stiches. More accessories are added on the cover of picture book media.

Table 4. students' responds in big-scale field test.

\begin{tabular}{|c|c|c|c|c|}
\hline \multirow[t]{2}{*}{ Aspect } & \multicolumn{2}{|c|}{ Item } & \multicolumn{2}{|c|}{ Children responds } \\
\hline & & & Yes & No \\
\hline \multirow[t]{5}{*}{ Design } & 1 . & $\begin{array}{l}\text { The cover picture is } \\
\text { attractive }\end{array}$ & $100 \%$ & $0 \%$ \\
\hline & 2. & $\begin{array}{l}\text { The book color is } \\
\text { interesting }\end{array}$ & $100 \%$ & $0 \%$ \\
\hline & 3 & $\begin{array}{l}\text { The kind and size of the } \\
\text { letter is easy to read }\end{array}$ & $100 \%$ & $0 \%$ \\
\hline & 4 & $\begin{array}{l}\text { The material of the media } \\
\text { is safe for children }\end{array}$ & $100 \%$ & $0 \%$ \\
\hline & 5 & $\begin{array}{l}\text { Material used in the } \\
\text { media can last for long } \\
\text { time }\end{array}$ & $83.94 \%$ & $16.06 \%$ \\
\hline \multirow[t]{7}{*}{ content } & 6 & $\begin{array}{l}\text { The material in the book } \\
\text { is easy to be understood } \\
\text { by children }\end{array}$ & $100 \%$ & $0 \%$ \\
\hline & 7. & $\begin{array}{l}\text { The pictures displayed in } \\
\text { the book are interesting }\end{array}$ & $100 \%$ & $0 \%$ \\
\hline & 8 & $\begin{array}{l}\text { The content of the story is } \\
\text { interesting }\end{array}$ & $100 \%$ & $0 \%$ \\
\hline & & $\begin{array}{l}\text { The media brings } \\
\text { exemplary values }\end{array}$ & $100 \%$ & $0 \%$ \\
\hline & 10. & $\begin{array}{l}\text { The media grow the } \\
\text { children's interest }\end{array}$ & $100 \%$ & $0 \%$ \\
\hline & & $\begin{array}{l}\text { The media grow the } \\
\text { children's motivation }\end{array}$ & $100 \%$ & $0 \%$ \\
\hline & & rage in percent & $83.94 \%$ & $16.06 \%$ \\
\hline
\end{tabular}

Based on the result of data analysis in the responds of children during the big-scale field test by using percentage of agreement formula, the point number $1,2,3,4,5,6,7,8,9,10,11$ have already reached $100 \%$, while point number 5 reached 83.95. Based on the result of analysis, it can be concluded that the items' score can be revised in small-scale field test and increased. While the problem of item number 5 about making the product last longer still have to be revised. The revision done are stitching the cover of picture book media with rough yarn so the cover won't come loose when used by children

In this research and product development, there are limitation done by the researcher (1) within the early reading component for children with 5-6 
years in age, there are only 3 components discussed which are visual description and perceptual motoric ability. It would be better if every component of early reading for children with 5-6 years in age are discussed completely (2) the product developed does not introduce every letter of alphabet (3) the attitude aspect is not fully observed, because the focus in this research is only on the early reading ability of children

\section{CONCLUSION}

The result of this picture book media development in early reading learning for 5 to 6 years old children based on the research and data analysis acquired are as the following:

(1) Based on observation and open interview which are then studied and adjusted with the needs of children and teachers in early reading learning, picture book media is a media that modifies comic into a learning media in form of a comic. The needs required in developing this media are (a) early reading material in which are visual discrimination, perceptual motoric ability, and early literacy set forth in picture illustration and tasks in picture book media with the motoric activities, (b) interesting lay out for children, interesting picture illustration for children, (d) selection of interesting colors, (e) effective sentences and (f) picture book design that is easy and comfortable to be used by children. The purpose of this media is to give alternative media for early ready learning of 5 to 6 years old students that is in accordance with their language development characteristics so that early reading learning is fun and meaningful for children.

(2) Based on the scores from experts and practitioners after studying and using this picture book media in field, the picture book media is considered feasible. The feasibility test of the product is conducted in two stages, which are small-scale and big-scale, and the criteria acquired is in "very good" category, so as the scores of each design content components that also receive "very good" scores, the average of children's responds acquired in percentage is in "good" category. based on big-scale field test, the scores given by teachers on the overall point, the criteria acquired is in "very good" category, so as the scores for each component from design and content components receive "very good" scores. The children's responds acquired are in "good" category.

The game of picture book is considered effective to be used for 5 to 6 years old children in early reading learning based on effectivity test conducted. The effectivity is acquired from data analysis of post-test of experiment and control classes. Based on the analysis and results of effectivity test, it is found that the value of sig (2tailed) is 0.03 which is smaller than 0.05 , so it can be concluded if there is a significant increase towards early reading ability of children.

\section{REFERENCES}

[1] Borg, w.R \& Gall, M.D(1983). Educational reseach: an introduction (4th ed) New York: Longman Inc.

[2] Brroks,P.J Kempe, V(2012) languange development. Great Britain: TJ International, Padstow, Cornwall.

[3] Education and Social Science (3rd ed.). Buckingham \& Philadephia: Open University Press.

[4] Mushfiroh, T.(2017) psikokolinguistik edukasional pskololinguistik untuk pendidikan bahasa. Yogyakarta.Tiara Wacana

[5] Weigel, D.J, Martin, .S \& Bennett, K.K (2010) pathways to literacy: connection between family assets and preschool childern emergent literacy skills. Journal of early childhood research.8.522

[6] Yarmi,Gusti.2008. pendekatan dan strategi pembelajaran bahasan dan sastra indonesia di SD. Jurnal pendidika penabur -No 11/tahun ke 7/ Desember 2008.jakarta: Universitas Negeri jakarta. 